\title{
Characterization of Acorn Fruit Oils Extracted from Selected Mediterranean Quercus Species
}

\author{
By W.M. Al-Rousan ${ }^{a, ~}{ }^{凶}$, R.Y. Ajo ${ }^{a}$, K.M. Al-Ismail ${ }^{b}$, A. Attlee $^{c}$, R. R. Shaker ${ }^{d}$ and T. M. Osaili ${ }^{d}$ \\ ${ }^{a}$ Department of Applied Science, Al-Huson University College, Al-Balqa' Applied University, Jordan \\ ${ }^{b}$ Faculty of Agriculture, University of Jordan, Jordan \\ ${ }^{\circ}$ Department of Clinical Nutrition and Dietetics, College of Health Sciences, University of Sharjah, \\ Sharjah, UAE \\ ${ }^{d}$ Dept. of Nutrition and Food Technology, Faculty of Agriculture, Jordan University of Science \\ and Technology, Jordan \\ Corresponding author:Walmm_53@yahoo.com
}

\section{RESUMEN}

\section{Caracterización de aceites de bellota extraídos de Especies de Quercus del Mediterráneo}

El presente estudio tuvo como objetivo identificar la composición de aceites de bellota de tres especies del grupo del roble blanco del Mediterráneo, Quercus Aegilops (QA), Quercus infectoria (QI) y Quercus calliprinus (QC). Las muestras fueron evaluadas por el contenido de aceite, parámetros físico-químicos del aceite, perfil de ácidos grasos, tocoferoles, compuestos fenólicos y esteroles. El contenido de aceite, expresado en peso seco encontrado fue de 3,40 a $7,51 \%$. Las constantes físico-químicas fueron: densidad 0,912-0,922, índice de refracción 1,4529 a 1,4645, extinción

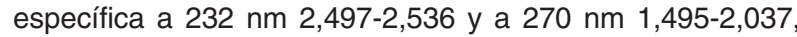
índice de yodo 75,2-87,6, e índice de saponificación 192,6219,4. Las composiciones de ácidos grasos se determinaron por GC como ésteres metilicos. Los ácidos grasos más abundantes fueron oleico $53,3-56,1 \%$, linoleico $21,3-23,4 \%$, palmítico $17,8-18,7 \%$, linolénico $1.5-1.6 \%$ y esteárico $1,02-$ $1,60 \%$. El contenido de tocoferoles fue alto: $1440-1783 \mathrm{mg}$ $\mathrm{kg}^{-1}$, constituyendo el $\gamma$-tocoferol entre el $84-91 \%$ de los tocoferoles totales. Los compuestos fenólicos estaban presentes en cantidades notables en las tres especies 84-109 mg de ácido gálico $\mathrm{kg}^{-1}$ aceite. El contenido total de esteroles fue de 2040-2480 $\mathrm{mg} \mathrm{kg}^{-1}$ de aceite, siendo el $\beta$-sitosterol el componente principal que comprende de $77,2-84,6 \%$, seguido de la $\Delta 5$-avenasterol 5.8-11.4, campesterol $3.6-4.5 \%$, y estigmasterol $2.6-3.8 \%$.

El contenido de colesterol fue relativamente alto $(0,42-$ $0,55 \%)$.

PALABRAS CLAVE: Aceite de bellota - Compuestos fenólicos - Esteroles - Perfil de ácidos grasos - Quercus spp. - Tocoferoles.

\section{SUMMARY}

Characterization of Acorn Fruit Oils Extracted from Selected Mediterranean Quercus Species

The present study is aimed to identifying the acorn fruit oil composition of three Mediterranean white oak group species, Quercus aegilops (QA), Quercus infectoria (QI), and Quercus calliprinus (QC). Samples were estimated for the oil contents of acorn fruits, oil chemical and physical constants, fatty acid profile, tocopherols, phenolic compounds, and sterols.
The oil content, expressed as dry weight, was found to be $3.40-7.51 \%$. The physical and chemical constants included specific gravity $0.912-0.922$, refractive index 1.4529-1.4645, specific extinction at $232 \mathrm{~nm} 2.497-2.536$ and at $270 \mathrm{~nm}$ 1.495-2.037, iodine value 75.2-87.6, and saponification value 192.6-219.4. The fatty acid compositions were determined by GC as methyl esters. The most abundant fatty acids were oleic (53.3-56.1\%), linoleic $21.3-23.4 \%$, palmitic $17.8-18.7 \%$, linolenic $1.5-1.6 \%$ and stearic acid $1.02-1.60 \%$. The Tocopherol content was high in the range of $1440-1783 \mathrm{mg} \mathrm{kg}^{-1}, \gamma$-tocopherol constituted $84-91 \%$ of total tocopherols. Phenolic compounds were in remarkable amounts in all the three species 84-109 mg gallic acid $\mathrm{kg}^{-1}$ oil. Total sterol contents were between $2040-2480 \mathrm{mg} \mathrm{kg}^{-1}$ oil, with $\beta$-sitosterol being the main component comprising of $77.20-84.61 \%$, followed by $\Delta^{5}$-avenasterol (5.8-11.4\%), campesterol (3.6-4.5\%), and stigmasterol (2.6-3.8). The cholesterol content was relatively high $(0.42-0.55 \%)$.

KEY-WORDS: Acorn oil - Fatty acid profile - Phenolic compounds - Quercus spp. - Sterols - Tocopherols.

\section{INTRODUCTION}

Oak acorns, one of the species of Quercus genus, are of vital importance for both humans and animals. Homo sapiens have been using acorns as food for thousands of years, wherever oaks exist. Oak is also considered an edible fruit in some Mediterranean countries as it used in ice cream and other desserts and liqueurs (León-Camacho et al., 2004; M'Hrit et al., 1998; Bainbridge, 1986). In Algeria, Morocco, and in the eastern U.S.A, acorn oil has been used as cooking oil and as a salve for burns and injuries (Smith, 1950; Hedrick, 1919). In Jordan, oak acorns have been used as food either directly or as an ingredient in products such as bread, cake, and coffee (Rababah et al., 2008; Jacknis, 2004). In addition, oak acorns have been extensively under exploitation as a fodder for cattle (Bouderoua and Selselet-Attou, 2003; Nowar et al., 1994; Al-Jassim et al., 1988).

Starch is the main component of acorns, amounting to over $55 \%$ of the kernel (Rababah 
et al., 2008). It contains moderate amounts of protein 2.75-8.44\% (Özcan, 2006), and fat 0.7$7.4 \%$ (Özcan, 2007). It also has a good content of minerals (Özcan et al., 2005).

Several studies have reported that the oil content of various white species of Quercus, did not exceed $12 \%$ (Rababah et al., 2008; Bernardo-Gil, 2007; Özcan, 2007; León-Camacho et al., 2004; M'Hrit et al., 1998), which indicates that acorn oil cannot be considered as commercial edible oil, BernardoGil et al., (2007) reported that the Portuguese legislation classified the acorn oil as an alimentary oil, although no industrial oil has been produced. However, some of $Q$. Erthrobalanus spp. (black and red oak group) contain 30.8-31.3\% oil, being similar to or higher than the best oil olives (Ofcarcik, 1971). In addition, acorn oils have good nutritional quality with a flavor comparable to that of olive oil (Özcan, 2007; Lopes et al., 2005; Bainbridge, 1986). It has been reported that the oleic acid and linoleic acid content in 16 acorns of Quercus taxa from Turkey were between 53-65\% and 24.2-49.1\%, respectively (Özcan, 2007).This justifies the fact that acorn oil should enjoy the respect of dietary reference for fatty acid intake, particularly linoleic acid, which is considered the most significant and valuable benefit to human health (Horrobin, 1983).

Furthermore, phenolic compounds and tocopherols, as natural antioxidants, are present in remarkable amounts in acorn fruits (Rakic' et al., 2007; Lopes et al., 2005). Therefore, acorn oils might exhibit oxidative stability and nutritional values similar to those of olive oil.

Oaks (Quercus spp.) are widely distributed throughout the Mediterranean region, and Jordan, has recently designated the Quercus aegilops as the national tree (MoA, 2003). The nutritional profile of oak acorn species in Jordan is lacking in the literature and its exploitation so far is not sufficient, particularly in human diets. Therefore, this study attempts to document the oak acorn oil content, crude oil physical and chemical constants, fatty acid profile, and some minor components, that commonly exist in oils for three species of acorns widely distributed throughout Jordan Quercus aegilops (QA), Quercus infectoria (QI), Quercus calliprinos (QC). It is also aimed at evaluating the nutritional value of the oil from the three acorn species as well as the potential use of these oils as a natural source of antioxidative substances, phytochemicals for the pharmaceutical, and food industry.

\section{MATERIALS AND METHODS}

\subsection{Raw materials}

Samples of acorn fruits were randomly collected from white oak trees of three species (QA, QI and $\mathrm{QC})$, from their natural distribution areas in the north of Jordan during the maturation season between November and January of 2009-2010. The samples collected were healthy, ripe fruits that had fallen to the ground without mechanical damage or insect deterioration. The collected samples were shelled, the kernels (cotyledons) were crushed and dried in an oven at $50^{\circ} \mathrm{C}$ for 3 days, and then the dried cotyledon were ground into ball meal and homogenized with pestle and mortar.

\subsection{Oil extraction}

The oils of the dried powder of cotyledon from the three species were extracted by the Soxhlet method using petroleum ether (bp 40-60 ${ }^{\circ} \mathrm{C}$ ), and were expressed on a dry-weight basis.

\subsection{Physical and chemical constants}

AOAC (1995) methods were used to determine the iodine, density and saponification values. The refractive index at $20^{\circ} \mathrm{C}$ was determined with a refractometer (Reichert. Abbe Mark III. USA), $K_{232}$ and $K_{270}$ extension coefficients were calculated from the absorption at $232 \mathrm{~nm}$ and $270 \mathrm{~nm}$, respectively with a spectrophotometer (Spectro UV-VIS Double beam PC, UVD-2950. Labomed, INC. USA) using a $1 \%$ solution of oil in cyclohexane.

\subsection{Fatty acid methyl esters}

The fatty acid composition was analyzed by GLC after derivatization to fatty acid methyl ester (FAMEs) with 2M KHO in methanol According to (IUPAC, 1995). The analysis of FAMEs was carried out with a GLC (model GC-2010, Shimadzu. Inc. Koyoto, Japan) equipped with a flame ionization detector and capillary column (Restek, Rtx225, USA, crossbond 50\%-cyanopropylmethyl $50 \%$-phenylmethyl polysiloxane, $60 \mathrm{~m}, 0.25 \mathrm{~mm} / \mathrm{D}$, $0.25 \mu \mathrm{m} \mathrm{df}$ ). The column oven temperature was $165^{\circ} \mathrm{C}$ for $10 \mathrm{~min}$, increased to $185^{\circ} \mathrm{C}, 1^{\circ} \mathrm{C} \mathrm{min}{ }^{-1}$ and kept at $185^{\circ} \mathrm{C}$ for $1 \mathrm{~min}$, then increased to $220^{\circ} \mathrm{C}, 3^{\circ} \mathrm{C} \min ^{-1}$ and kept at $220^{\circ} \mathrm{C}$ for $20 \mathrm{~min}$. The injector temperature was $240^{\circ} \mathrm{C}$ and the flame ionization detector temperature was $260^{\circ} \mathrm{C}$. The flow rate was $0.8 \mathrm{~mL} \mathrm{~min}^{-1}$ with a helium and split ratio of 80 . The (FAMEs) were identified using a chromatogram of fatty acid standards (12-24 carbon atoms) (Sigma)

\subsection{Tocopherols analysis}

The tocopherols were quantified by the HPLC method (Katsanidis, 1999), which consisted of a Knauer pump and a knauer and smartline 2500 UV detector (Advanced Scientific Instrument, Berlin, Germany). Acorn oil samples were dissolved in $n$-hexane $0.36 \%(w / v), 20 \mu \mathrm{L}$ of the solution was injected into a silica column (thermoQuest, $10 \mu$ particle size, $4.0 \mathrm{~mm} \mathrm{ID} \times 30 \mathrm{~cm})$. The mobile phase was hexane-isopropanol (99:1). The flow rate was $1.3 \mathrm{ml} \mathrm{min}{ }^{-1}$. The wavelength was programmed at $295 \mathrm{~nm}$. 


\subsection{Phenolic compounds}

The total phenolic content in acorn oils was determined using the Folin-Ciocalteu method (Gutfinger, 1981). Briefly, $10 \mathrm{~g}$ acorn oil were dissolved in $50 \mathrm{~mL}$ hexane. Twenty $\mathrm{mL}$ of aqueous methanol $(60 \%)$ were added and mixed vigorously for 2 minutes. The methanolic phase was removed and placed in a beaker each time after the two phases were separated. The combined extracts were laid out to dryness in a vacuum rotary evaporator at $70^{\circ} \mathrm{C}$. The residue was dissolved in $1 \mathrm{~mL}$ methanol. $0.1 \mathrm{~mL}$ from the methanolic extract was placed into a $10 \mathrm{ml}$ volumetric flask. $5 \mathrm{~mL}$ distilled water and $0.25 \mathrm{~mL}$ Folin Ciocalteau $(2 \mathrm{~N})$ were added and mixed well for $3 \mathrm{~min}$. One $\mathrm{mL}$ of $\mathrm{Na}_{2} \mathrm{CO} 3$ (about $35 \%$ ) was added and the flask was filled with distilled water up to the mark. The specific absorbance of the blue color formed was measured, after 1 hour, at $725 \mathrm{~nm}$ (Spectro UV-VIS Double beam PC, UVD2950. Labomed, INC. USA). A reference curve was prepared using gallic acid as the most representative phenolic standard, and expressed as $\mathrm{mg}$ gallic acid $\mathrm{g}^{-1}$ of oil.

\subsection{Sterols}

Acorn oil samples (five grams) were saponified according to Frega et al., 1992, with $1 \mathrm{mg}$ $\alpha$-cholestanol as internal standard with $50 \mathrm{~mL}$ of $2 \mathrm{~N} \mathrm{KOH}$ in methanol for $1 \mathrm{~h}$ under reflux. The unsaponifiable fraction was extracted three times with 80,70 and $60 \mathrm{~mL}$ diethyl ether. The pooled extract was then washed several times with $50 \mathrm{~mL}$ water until the washing solution became colorless with phenolphthalein. The solvent was removed under low pressure using a vacuum rotary evaporator. The unsaponifiable fraction was dried under nitrogen flow, dissolved in chloroform $(10 \%$ solution, w/v) and loaded onto $10 \mathrm{~cm}$ of a silica TLC plate (about $20 \mu \mathrm{L}$ of chloroformic solution/ $\mathrm{cm}$ ); a spot containing sterol standards $((\beta$-sitosterol) was loaded onto the same TLC plate, so as to correctly identify the sterol band. The mobile phase was a mixture of $n$-hexane-diethyl ether $(65: 35, \mathrm{v} / \mathrm{v})$. The sterol TLC band was visualized at $254 \mathrm{~nm}$, after being sprayed with a $0.2 \%$ ethanolic solution of 2',7'-dichlorofluorescein sodium salt. The sterol band was then scraped off, extracted twice with $5 \mathrm{~mL}$ of diethyl ether and the solvent was evaporated under nitrogen flow at room temperature. The solution containing the sterol TLC band was then silylated with $200 \mu \mathrm{L}$ of a pyridine-hexamethyldisilazanetrimethylchlorosilane $(9: 3: 1, \mathrm{v} / \mathrm{v})$ mixture; after 15-20 min at room temperature, the sample was evaporated to dryness under nitrogen flow and dissolved in $100 \mu \mathrm{L}$ of $\mathrm{n}$-hexane. The derivatized unsaponiables were analyzed with a Shimadzu GLC (model 2010, Japan) coupled to an FID detector. They were separated on a GC non-polar column (Restek, USA, cross-bond 5\%-diphenyl 95\%-dimethyl polysiloxane, $30 \mathrm{~m}, 0.25 \mathrm{~mm}$ id, $0.1 \mu \mathrm{m} d f)$. The oven temperature was programmed from 200 to $300^{\circ} \mathrm{C}$ at a rate of $3^{\circ} \mathrm{C} \mathrm{min}$ meld at $^{-1}$ and held this temperature for $10 \mathrm{~min}$; helium was the carrier gas at a flow rate of $0.8 \mathrm{~mL} \mathrm{~min}^{-1}$. The injector and detector temperatures were $300^{\circ} \mathrm{C}$.

\subsection{Statistical Analysis}

A statistical analysis of the experiment results was performed on the Microsoft office excel program. All experiments were carried out in triplicate; results are expressed as means \pm standard deviations (SD).

\section{RESULTS AND DISCUSSION}

The oil contents of acorn cotyledons of the species QA 7.51\%, and QI 6.57\%, were about two times higher than that of QC $3.40 \%$. This result agrees with the results reported by (Özcan, 2006 and Lopes et al., 2005) who found that the oil content of some species of acorn ranged between 3.8 and $9.1 \%$. This indicates that the oil content of these acorn species is low for commercial production as cooking or frying oils. However, there is a possibility of using this kind of oil as a supplement ingredient in products such as baked goods that may help improve their quality and considerably reduce their costs. In addition, acorn oil might be considered similar to other plant oil sources because of its health benefits or industrial and pharmaceutical applications, as in the case of amaranth and wheat germ, whose oil contents are about $6.34 \%$ and $10 \%$, respectively (LeónCamacho et al, 2001; Sonntag, 1979).

The physical and chemical constants estimated in the oil extracted from the three $Q$. species are shown in Table1. As revealed, acorn oil is similar to olive oil in most specifications, except UV absorption at $270 \mathrm{~nm}$, which ranged from 1.495-2.037. This range is several times higher than that reported for olive oil (0.3). This can be attributed to the high positive correlation between the oil content of bitter compounds and the UV absorbance (GarcíaMesa et al., 1992). Some of these compounds are tannins which might be dissolved in the acorn oil during extraction, thus the UV absorption at $270 \mathrm{~nm}$ which we obtained is rational.

Based on iodine value, which ranged from 75-88, acorn oil might be classified as a non-drying oil; Duel (1951) proposed that an iodine value above 100 means an oil is to be classified as drying while below 100 is non-drying. The obtained oils were clear yellow in QI, while the color was yellow-brown for $\mathrm{QA}$, and QC. On the other hand, the saponification value for the three species was slightly higher than that of olive oil, a result which is in good agreement with the reported findings by (Mamedova et al., 1993).

Table 2 gives an overview of the content of individual fatty acids (FAs) and their proportions in the three species of Quercus under study. As shown, the most abundant fatty acids were oleic $55.6,56.1,53.3 \%$, followed by linoleic $21.7,21.3$, 
Table 1

Physical and chemical parameters of Quercus spp. oils

\begin{tabular}{lccccc}
\hline \multicolumn{1}{c}{ Parameters } & QA & QI & QC & Q. castaneiflia $^{\mathbf{b}}$ & Olive oil $^{\mathbf{c}}$ \\
\hline Specific gravity & $0.912 \pm 0.005^{\mathrm{a}}$ & $0.922 \pm 0.005$ & $0.918 \pm 0.005$ & 0.9182 & $0.910-0.916$ \\
Refractive index at $25^{\circ} \mathrm{C}$ & $1.4645 \pm 0.0012$ & $1.4595 \pm 0.0011$ & $1.4529 \pm 0.0011$ & 1.4738 & $1.4677-1.4705$ \\
Specific extinction at $232 \mathrm{~nm}$ & $2.525 \pm 0.002$ & $2.536 \pm 0.002$ & $2.497 \pm 0.002$ & - & $\leq 3.5$ \\
Specific extinction at $270 \mathrm{~nm}$ & $1.495 \pm 0.001$ & $2.037 \pm 0.002$ & $1.686 \pm 0.001$ & - & $\leq 0.3$ \\
lodine value & $87.6 \pm 2.0$ & $76.7 \pm 2.1$ & $75.2 \pm 1.9$ & 112.7 & $75-94$ \\
Saponification value & $204.2 \pm 4.5$ & $219.4 \pm 4.7$ & $192.6 \pm 3.9$ & 193.7 & $184-196$ \\
\hline
\end{tabular}

QA- Quercus aegilops; QI- Quercus infectoria; QC- Quercus calliprinos.

${ }^{a}$ Each value is the mean of three replications followed by SD.

${ }^{\mathrm{b}}$ Mamedova et al. (1993).

${ }^{c}$ IOOC (1995).

Table 2

Fatty acid profile of the three Acorn Species of the Genus Quercus, including some of their ratios

\begin{tabular}{lcccccc}
\hline \multicolumn{1}{c}{ Fatty acid } & QA & QI & QC & Q. suber L & Q. brantii $^{\text {c }}$ & Olive Oil $^{\text {d }}$ \\
\hline Myristic (C14:0) & $0.17 \pm 0.01^{\mathrm{a}}$ & $0.12 \pm 0.01$ & $0.13 \pm 0.01$ & 0.1 & 0.0 & $\leq 0.1$ \\
Palmitic (C16:0) & $18.7 \pm 0.6$ & $17.8 \pm 0.6$ & $18.4 \pm 0.6$ & 14.36 & 13.5 & $7.5-20.0$ \\
Palmitoleic (C16:1) & $0.19 \pm 0.01$ & $0.25 \pm 0.01$ & $0.26 \pm 0.01$ & 0.5 & 0.2 & $0.3-3.5$ \\
Heptadecanoic (C17:0) & $0.16 \pm 0.01$ & $0.46 \pm 0.01$ & $0.31 \pm 0.01$ & 0.1 & 0.1 & - \\
Cis-10-heptadecanoic (C17:1) & $0.13 \pm 0.01$ & $0.22 \pm 0.01$ & $0.14 \pm 0.01$ & 0.0 & 0.1 & - \\
Stearic (C18:0) & $1.02 \pm 0.09$ & $1.5 \pm 0.1$ & $1.6 \pm 0.1$ & 1.2 & 1.9 & $0.5-5.0$ \\
Oleic (C18:1) & $55.6 \pm 1.6$ & $56.1 \pm 1.6$ & $53.3 \pm 1.5$ & 57.95 & 54.3 & $55.0-83.0$ \\
Linoleic (C18:2) & $21.7 \pm 1.0$ & $21.3 \pm 1.0$ & $23.4 \pm 1.0$ & 21.95 & 24.2 & $3.5-21.0$ \\
Linolenic (C18:3) & $1.6 \pm 0.1$ & $1.6 \pm 0.1$ & $1.5 \pm 0.1$ & 2.6 & 1.5 & $\leq 0.9$ \\
Arachidic (C20:0) & $0.18 \pm 0.01$ & $0.22 \pm 0.02$ & $0.22 \pm 0.02$ & 0.2 & 0.4 & $\leq 0.6$ \\
Eicosenoic (C20:1) & $0.32 \pm 0.02$ & $0.36 \pm 0.03$ & $0.35 \pm 0.04$ & 0.6 & 0.7 & $\leq 0.4$ \\
Behenic (C22:0) & $0.12 \pm 0.00$ & $0.10 \pm 0.00$ & $0.11 \pm 0.00$ & - & 0.3 & $\leq 0.2$ \\
Lignoceric acid (C24:0) & $0.17 \pm 0.00$ & $0.24 \pm 0.00$ & $0.24 \pm 0.00$ & - & 0.2 & $\leq 0.2$ \\
Total saturated (\%) & 20.52 & 20.44 & 21.01 & 15.96 & 16.4 & 55.3 \\
Mono unsaturated (\%) & 56.24 & 56.93 & 54.05 & 59.05 & 24.55 & 25.7
\end{tabular}

QA- Quercus aegilops; QI- Quercus infectoria; QC- Quercus calliprinos.

${ }^{a}$ Each value is the mean of three replications followed by SD.

b León-Camacho et al. (2004).

c Özcan (2007).

d IOOC (1995).

$23.4 \%$, and palmitic $18.7,17.8,18.4 \%$ in the acorn oil of QA, QI, and QC species, respectively. The minor variations in fatty acid levels observed between our three species and other species (performed by other investigators) might be related to the difference in acorn varieties, environmental conditions, and oak acorn maturity.

The oleic and linoleic acid percentages were in accordance with earlier findings (León-Camacho et al., 2004; Bouderoua and Selselet-Attou, 2003), whereas the palmitic acid content was higher than reported.

As listed in table 2, the fatty acid composition of acorn oil is comparable to that of olive oil, particularly, in terms of the three abundant FAs (oleic, linoleic and palmitic acid), which together constituted $95 \%$ of the total fatty acids. The linoleic acid content of acorn oil samples is slightly higher than that of olive oil, therefore, from a nutritional point of view, acorn oil may be considered healthier for the human diet.

The ratio of the unsaturated fatty acids to the saturated fatty acids was about 3.9:1; this high ratio may be attributed to the high content of linoleic acid.

It is well-known that natural antioxidants such as tocopherols have a positive correlation with the unsaturated fatty acids (León-Camacho et al., 2004). 
Table 3 shows a comparison of the tocopherol contents in the oil from the three spp. selected in the current study and other vegetable oils. The findings reveal that the total content of tocopherols in the present study ranged from $1440-1783 \mathrm{mg} \mathrm{kg}^{-1}$ oil, which is higher than its content in other vegetable oils. This implies that the oil from the three species is expected to have resistance to oxidation. The main tocopherol was $\gamma$-tocopherol, forming almost $90 \%$ of the total tocopherol content. This difference in the total tocopherol contents of the three species with olive and peanut oils may be attributed to the higher content of $\gamma$-tocopherol in acorn oils. On the other hand, $\alpha$-tocopherol content was comparable with the content in olive or peanut oil.

Phenolic compounds are a natural antioxidant agent that exists in oil. The amount of phenolic compounds extracted during production is fundamental for the oxidative and nutritional quality of the oil. The total phenolic compound contents were $84,95,109 \mathrm{mg} \mathrm{kg}^{-1}$ for the oils of QA, QI, QC, respectively. Certainly, this amount of phenolics will increase the oxidative stability of the oil. Since no prior experiment on the acorn oil content of phenolic compounds has been reported, the reliability of the results in the present study is difficult to establish. However, a related review of the literature depicts that the usual value for virgin olive oil ranges between 100 and $300 \mathrm{mg} \mathrm{kg}^{-1}$ (Andrewes et al., 2003). This indicates that the acorn oils contain significant amounts of phenolic compounds.

Sterols are the major constituents of the unsaponifiables in vegetable oils. They have cholesterol-lowering properties, and may protect from heart disease. Recently they are incorporated into a growing spectrum of functional foods, as they are added to dairy products, bakery goods, sausages, and fruits juices (Garcia-Llatas et al., 2011).

Table 4 delineates the distribution of sterols in the oil from the three acorn species in this study and other oils. The total sterol contents were

Table 3

Tocopherol contents ( $\mathrm{mg} \mathrm{kg}^{-1}$ ) in Quercus spp. oils

\begin{tabular}{lcccccc}
\hline Tocopherols & QA & QI & QC & QS $^{\text {b }}$ & Olive oil $^{\mathbf{c}}$ & Peanut $^{\mathbf{c}}$ \\
\hline$\alpha$-tocopherol & $230 \pm 3^{\mathrm{a}}$ & $171 \pm 2$ & $141 \pm 2$ & 205 & 240 & 230 \\
$\beta$-tocopherol & ND & ND & ND & - & traces & \\
$\gamma$-tocopherol & $1210 \pm 3$ & $1612 \pm 3$ & $1501 \pm 5$ & $1281^{\mathrm{e}}$ & traces & $310^{\mathrm{d}}$ \\
Total & 1440 & 1783 & 1642 & 1486 & 240 & 540 \\
\hline
\end{tabular}

QA- Quercus aegilops; QI- Quercus infectoria; QC- Quercus calliprinos; QS- Quercus suber L.

${ }^{a}$ Each value is the mean of three replications followed by SD.

${ }^{\mathrm{b}}$ Teresa et al. (1977).

${ }^{c}$ Kiritsakis et al. (1998).

${ }^{d}$ this value for $\beta+\gamma$ tocopherols.

${ }^{\mathrm{e}}$ this value for $\gamma+\delta$ tocopherols.

ND: not detected.

Table 4

Distribution (\%) and total sterol contents ( $\left.\mathrm{mg} \mathrm{kg}^{-1}\right)$ in Quercus spp. oils

\begin{tabular}{|c|c|c|c|c|c|c|}
\hline Sterol & QA & QI & QC & $Q^{b}$ & $Q^{c}$ & $00^{d}$ \\
\hline cholesterol & $0.55 \pm 0.03$ & $0.42 \pm 0.02$ & $0.44 \pm 0.02$ & 1.16 & 0.10 & $0-0.1$ \\
\hline campesterol & $4.50 \pm 0.21$ & $3.60 \pm 0.17$ & $3.90 \pm 0.19$ & 3.40 & 10.20 & $0-0.5$ \\
\hline campestanol & $0.07 \pm 0.00$ & $0.08 \pm 0.00$ & $0.07 \pm 0.00$ & 0.11 & 0.18 & - \\
\hline stigmasterol & $3.02 \pm 0.15$ & $2.60 \pm 0.09$ & $3.80 \pm 0.18$ & 11.45 & 3.61 & $0-4.0$ \\
\hline chlerosterol & $0.35 \pm 0.01$ & $0.34 \pm 0.01$ & $0.34 \pm 0.01$ & 1.16 & 1.12 & - \\
\hline$\beta$-sitosterol & $84.61 \pm 3.11$ & $77.20 \pm 2.59$ & $78.70 \pm 2.08$ & 75.92 & 83.52 & $75-80$ \\
\hline$\Delta^{5}$-avenasterol & $5.80 \pm 0.27$ & $11.40 \pm 1.45$ & $9.30 \pm 0.47$ & 4.20 & 0.36 & $4-14$ \\
\hline$\Delta^{5,24}$-stigmastadienol & $0.35 \pm 0.01$ & $0.30 \pm 0.01$ & $0.75 \pm 0.03$ & 0.75 & 0.33 & - \\
\hline$\Delta^{7}$-stigmastenol & $0.32 \pm 0.01$ & $0.30 \pm 0.01$ & $0.38 \pm 0.01$ & 0.40 & 0.11 & $0-0.5$ \\
\hline$\Delta^{7}$-avenasterol & $0.24 \pm 0.01$ & $0.24 \pm 0.01$ & $0.25 \pm 0.01$ & 0.09 & 0.06 & - \\
\hline Total $\left[\mathrm{mg} \mathrm{kg}^{-1}\right]$ & 2480 & 2040 & 2300 & 8563 & 4764 & 100 \\
\hline
\end{tabular}

QA- Quercus aegilops; QI- Quercus infectoria; QC- Quercus calliprinos; QF- Quercus faginea; QS- Quercus suber L; O O- Olive Oil.

${ }^{a}$ Each value is the mean of three replications followed by SD.

b León-Camacho et al. (2004).

${ }^{c}$ Lopes et al. (2005).

${ }^{\mathrm{d}}$ Kiritsakis et al. (1998) 
$2040-2480 \mathrm{mg} \mathrm{kg}^{-1}$ oil, this content of sterols is considered low as compared to the sterol contents of $Q$. suber L.; and $Q$. faginea $L$., but higher than olive oil content. $\beta$-sitosterol constituted 77.20$84.61 \%$ of the total sterol fraction. This is in agreement with results presented earlier (LeónCamacho et al., 2004; Lopes et al., 2005), and consistent with values for olive oil. $\beta$-sitosterol is the main sterol followed by $\Delta^{5}$-avenasterol $5.8-11.4 \%$, campesterol $3.6-4.5 \%$ and stigmasterol $2.6-3.8 \%$. The $\Delta^{5}$-avenasterol values lied well within the olive oil limits, but campesterol and stigmasterol values determined in the current study were comparable with values reported in $Q$. faginea and $Q$. suber $L$ performed by (Lopes et al., 2005, León-Camacho et al., 2004).

\section{CONCLUSIONS}

The present study brings new insight into the three species of Jordanian acorn, particularly their oil composition. A close comparison with that of olive oil was exposed, particularly, in terms of constant parameters (iodine, saponification values), fatty acid profile, and sterols. Moreover, the tocopherol content in acorn oil is higher than numerous vegetable oils including olive oil, while the phenolic compounds exist in notable concentrations. The significant contents of tocopherol, sterol and phenolic compounds attribute oxidative stability to the acorn oil.

Furthermore, the results point out that acorn oil has a potential value for healthy human uses, as they contain various biological active compounds (linoleic acid, tocopherols, sterols, and phenolic compounds). Thus, acorn oil might be considered as a functional food and used in food preparation.

Finally, further studies to identify and develop oak cultivars for acorn meal, nut, and oil production are recommended.

\section{ACKNOWLEDGEMENTS}

We wish to thank Al-Balq'a Applied University/ Jordan for their support for this research.

\section{REFERENCES}

Al-Jassim R, Ereifej K, Shibli R, Abudabos A. 1988. Utilization of concentrated diets containing acorns (Quercus aegilops and Quercus coccifera) and urea by growing Awassi lambs. Small Ruminant Res. 29 289-293.

Andrewes P, Busch J L H C, De Joode T, Groenewegen A, Alexandre H. 2003. Sensory properties of virgin olive oil polyphenols: Identification of deacetoxyligstroside aglycon as a key contributor to pungency. J. Agric. Food Chem. 51, 1415-1420.

AOAC (1995). Official methods of analysis of the Association of Official Analytical Chemists (16 ${ }^{\text {th }}$ ed.). Gaithersburg, MD: AOAC International.
Bainbridge D. 1986. Use of acorns for food in California: past, present, future. Multiple-use management of California's hardwoods Symposium, November 1214, San Luis Obispo, California.

Bernardo-Gil M, Lopes I, Casquilho M, Ribeiro M, Mercedes M, Empis J. 2007. Supercritical carbon dioxide extraction of acorn oil. J. Supercritical Fluids 40, 344-348.

Bouderoua K, Selselet-Attou G. 2003. Fatty acid composition of abdominal adipose tissue in broilers fed green-oak (Quercus ilex), cork oak acorn (Quercus Suber L.) based diets. Anim. Res. 52, 377-382.

Duel H J. 1951. The Lipids: Their Chemistry and Biochemistry. 1:53-57.

Frega N, Bocci F, Lercker G. 1992. Direct gas chromatographic analysis of the unsaponifiable fraction of different oils, by using a polar capillary column. J. Am. Oil Chem. Soc. 69, 447-450.

Garcia-Llatas G, Rodriguez-Estrada M. 2011. Current and new insight phytosterol oxides in plant sterolenriched food. Chem. Phys. Lipids 164, 607-624.

García-Mesa J A, Luque de Castro M D, Valcárcel M. 1992. Direct automatic determination of bitterness in virgin olive oil by use of a flow injection-sorbent extraction system. Anal. Chim. Acta 261, 367-374.

García Teresa R, Buron Arias I. 1977. Estudio comparativo de las propiedades quimicas y fisicoquimicas del aceite de bellota y de otros aceites comestibles. In: Anales del Instituto Nacional de Investigaciones Agrárias (INIA): Tecnologia Agraria. 4, 123-148.

Gutfinger T. 1981. Polyphenols in olive oils, J. Am. Oil Chem. Soc. 58, 966-968.

Hedrick U. 1919. Sturtevant's Notes on Edible Plants. Report of the New York Agric. Exp. Station, 20. Albany, NY.

Horrobin D, Manku M. 1983. How do polyunsaturated fatty acids lower plasma cholesterol levels? Lipids. 18, 558-562.

IOOC, International Olive Oil Council 2003. Trade standard applying to olive oil and olive-pomace oil. COI/ T.15/NC no. 2/Rev. 2, Madrid, Spain.

IUPAC 1995. Standard methods for the analysis of oils, fats and derivatives, $6^{\text {th }}$ edn (method II. D. 19). Pergamon Press, Oxford, pp 96-102.

Jacknis I. 2004. Food in California Indian Culture, Hearst Museum Publications, Berkeley, CA.

Katsanidis E, Addis P. 1999. Novel HPLC analysis of tocopherols, tocotrienols and cholesterol in tissue. Free Radical Bio Med. 27, 1137-1140.

Kiritsakis A K, Lenart E B, Willet W C, Hernandez R J. 1998. Olive Oil from the Tree to the Table, $2^{\text {nd }}$ edition, Food \& Nutrition Press, INC. Trumbull, Connecticut, 06611. USA. PP. 123.

León-Camacho M, Viera-Alcaidea I, Vicario I. 2004. Acorn (Quercus spp.) fruit lipids: saponifiable and unsaponifiable fractions: a detailed study, J. Am. Oil Chem. Soc. 81, 447-453.

León-Camacho M, Garcia-González DL, Aparicio $\mathrm{R}, 2001$. A detailed and comprehensive study of amaranth (Amaranthus cruentusL.) oil fatty profile. Eur. Food Res. Technol. 213, 349-355.

Lopes I, Bernardo-Gil M. 2005. Characterisation of acorn oils extracted by hexane and by supercritical carbon dioxide, Eur. J. Lipid Sci. Technol. 107, 12-19.

M'Hrit O, Benzyane M, Varrela MC Le chene-Liège au 1998. Maroc: Stratégie de Conservation et d'Amélioration. Ann Rech For Maroc (Special Issue): 127-144. 
Mamedova, M E, Aslanov S M , Mirzoev O G. 1993. Chemical composition of the acorns of Quercus Castneifolia. Chem. Nat. Compd. 29, 609-610.

MoA, Ministry of Agriculture. 2003. "National Strategy for Agricultural Development". Amman, Jordan.

Nowar M, Al-Shawabkeh K Nissour H. 1994. Evaluation of Oak Acorn (Quercus coccifera) as Untraditional Energy Feedstuff for Complete Substitution of Corn Grains in Fattening Rabbit Ration. In: Rabbit Production in Hot Climates, Baselga, M. and I.F.M. Marai (Eds.), Zaragoza: CIHEAM-IAMZ: International Conference of Rabbit Production in Hot Climates, 1994/09/06-08, Cairo (Egypt), pp: 177-182.

Ofcarcik RP, Burns EE, Teer JG. 1971. Acorns for Human Food. Food Ind. Journal, 4,18

Özcan T. 2007. Characterization of Turkish Quercus L. Taxa Based on Fatty Acid Compositions of the Acorns. J. Am. Oil Chem. Soc. 84, 653-662.

Özcan T. 2006. Total protein and amino acid compositions in the acorns of Turkish Quercus L. taxa. Genet. Resour. Crop. Ev. 53, 419-429.
Özcan T, Gülríz B. 2005. Some Elemental Concentrations in the Acorns of Turkish Quercus L. (Fagaceae) Taxa. Pak. J. Bot. 37, 361-371.

Rababah T, Ereifej K, Al-Mahasneh M., Alhamad M., Alrababah M., and Al-u'datt M.

2008. The Physicochemical Composition of Acorns for Two Mediterranean Quercus Species, Jordan J. Agric. Sci. 4, 131-137.

Rakic' S, Petrovic' S, Kukic' J, Jadranin M, Teševic' V, Povrenovic' D, Šiler-Marinkovic S. 2007. Influence of thermal treatment on phenolic compounds and antioxidant properties of oak acorns from Serbia. Food Chem. 104, 830-834.

Smith J. 1950. Tree Crops: a permanent Agriculture, old Greenwich. Connecticut Devin-Adair, Co.

Sonntag N. 1979. Composition and Characteristics of Individual Fats and Oils, in Swern D. (Ed.) Bailey's Industrial Oil and Fat Products, 4th ed. John Wiley \& Sons, New York, Vol. 1, pp. 289-478.

Recibido: $4 / 2 / 13$ Aceptado: $5 / 8 / 13$ 